\title{
FREE SPEECH IN THE UNITED STATES AND CANADA
}

\author{
Kent Greenawalt*
}

\section{INTRODUCTION}

This comparison of freedom of speech in the United States and Canada concentrates on Supreme Court decisions in the two countries and on kinds of speech mainly engaged in by extreme dissenters and political outsiders. After brief comments about constitutional language and general approaches, I discuss subversive speech and other speech that encourages criminal acts, hate speech, symbolic speech, and public demonstrations. ${ }^{1}$

In both countries, a major premise of modern adjudication is that freedom of expression is a central feature of liberal democracy. Government "by the people," even in the extended sense of government by representatives, requires that citizens openly debate the merits of candidates and policies. Under prevailing liberal democratic theory, open discourse is more conducive to discovering truth than is government selection of what the public hears. Free statement of personal beliefs and feelings is an important aspect of individual autonomy.

In recent years, some critics of the liberal democratic theory have claimed that existing liberty of speech reinforces false consciousness, social inequality, and domination by protecting the expression of those already in power and failing to open channels for the dispossessed. ${ }^{2}$ The particular areas I consider are significant ones in response to that critique.

\section{Copyright $\odot 1992$ by Law and Contemporary Problems \\ * University Professor, Columbia University School of Law.}

In this article I briefly cover a number of subjects on which I have written. I regard the article primarily as an introductory comparative study. However, I do in passing indicate some views that are developed at length in Kent Greenawalt, Speech, Crime, and the Uses of Language (Oxford U Press, 1989); Kent Greenawalt, $O^{\prime}$ er the Land of the Free: Flag Burning as Speech, 37 UCLA L Rev 925 (1990); and Kent Greenawalt, Insults and Epithets: Are They Protected Speech?, 42 Rutgers L J 287 (1990). I have limited citations mainly to cases to which I directly refer, and to Canadian writings that are not mentioned in the book. The book contains fairly extensive citations for most of the subjects covered here.

I have received extremely valuable research help from Michael Dowdle, who discovered sources and helped me develop my initial plans for the article, and from Shauna Van Praagh, who made me aware of very recent decisions, educated me about important features of Canadian law and practice, and gave insightful criticisms of an earlier draft.

1. For these topics, no particular aspect of the press is significant, and I use the term "free speech" to cover "free press" as well as free speech.

2. It is one of the ironies of the recent past that while neo-Marxists in Western democracies have challenged the liberal vision of freedom of speech, citizens of countries with official Marxist ideologies have put their lives on the line to achieve some form of liberal free speech. 
The United States and Canada are at different stages in the development of constitutional free speech doctrines. American principles, based on the 200 year-old Bill of Rights, have grown over the last seventy years with very limited attention to documents and judicial rulings of other countries. Although preceded by some judicial elaboration of ideals of free expression, the Canadian Charter of Rights and Freedoms drastically altered Canada's constitutional landscape in 1982. Canadian courts have drawn extensively from the legal materials of other countries, including the United States, and from sources in international law. They have regarded themselves, to a degree so far uncharacteristic in the United States, as giving meaning to liberties that transcend national boundaries.

\section{Constitutional Language and General Approaches}

One critical inquiry in free speech cases asks what falls within the definition of speech. Another critical inquiry asks what constitutes interference with speech. How stringently courts will review government actions that interfere with speech is also a central concern. In respect to each question, judicial approaches may be expansive or modest, and they may be balancing or conceptual.

An expansive approach understands speech broadly, to include virtually all written and oral communication, fine arts and music, demonstrations, and symbolic acts such as flag burning. An expansive approach treats indirect threats to speech as well as focused interference as raising constitutional questions. A modest approach defines the limits of constitutional speech more closely, perhaps not including private communications about private subjects, demonstrations, or physical acts such as flag burning. Under a modest approach, it is assumed that no constitutional issue is raised by a government practice that is not aimed at speech. An expansive approach to the scope of judicial review of allegedly impermissible interference regards impairments of speech with skepticism and requires a heavy burden to justify them. A modest approach permits impairments under fairly relaxed standards of review.

Balancing approaches to decision openly weigh crucial factors; conceptual approaches employ categorical analysis. A rule that a practice is invalid unless sustained by a compelling interest relies on balancing. A rule that defamation of public officials is protected unless there is knowledge or reckless disregard of falsity is categorical. ${ }^{3}$ Of course, conceptual approaches typically reflect some underlying balance of rights and interests. In addition, many applicable standards employ a combination of conceptual and balancing approaches. For instance, if "content distinctions" can be upheld only upon an extremely

3. But note that, to a degree, recklessness itself is a balancing concept, because the benefit of action is weighed against the risk of harm. 
strong showing of government need, then content distinction operates as an important category that triggers highly stringent balancing review.

Constitutional language and broader traditions concerning review of legislative and executive action will largely determine the approaches a country's judiciary takes. The language of the U.S. Constitution is rather unrevealing. The first amendment states "Congress shall make no law ... abridging the freedom of speech, or of the press ...." The "the" preceding "freedom of speech" might have been taken to mean whatever freedom of speech then existed at common law, but courts have declined this limiting perspective. Despite the specific language about "Congress," the clause as construed covers any abridgement of free speech by any officer of the federal government. The fourteenth amendment, with its requirements that states not deprive persons of due process of law or abridge the privileges or immunities of citizens, has been held to make the first amendment applicable to the states. ${ }^{4}$ Since the American Constitution does not provide for government justifications of violations of guaranteed individual rights, ${ }^{5}$ a court's formal determination that free speech has been abridged is necessarily a formal decision that the government action was impermissible.

The Canadian Charter of Rights and Freedoms is strikingly different in important respects. Section 2 provides that everyone has the fundamental freedoms of "thought, belief, opinion and expression, including freedom of the press and other media of communication."' 6 The Charter explicitly applies to the national and the provincial governments. Under section 1 of the Charter, fundamental freedoms are subject "to such reasonable limits prescribed by law as can be demonstrably justified in a free and democratic society." According to section 33(1), Parliament or a provincial legislature may, by making an express declaration that its action complies with section 1 , adopt legislation notwithstanding the protections of section 2. A Canadian court may thus decide that an act limits freedom of expression under section 2 but is nonetheless effective because it satisfies the standard of section 1 or has been shielded by an express legislative declaration. ${ }^{7}$

These differences in constitutional language might be expected to yield variances in judicial approach. ${ }^{8}$ The basic American constitutional standard of "abridging the freedom of speech" seems to call for conceptual

4. State constitutions typically include their own guarantee of freedom of speech. These constitutions, cast in variant language, provide the basis for invalidating many state practices that impair speech.

5. The Constitution does, however, allow suspension of the writ of habeas corpus "when in Cases of Rebellion or Invasion the public Safety may require it." US Const, Art I, $\$ 9$.

6. The Charter also includes freedom of conscience as a part of "freedom of conscience and religion." Can Const (Constitution Act, 1982) pt I (Canadian Charter of Rights and Freedoms), $\S 2(\mathrm{a})$.

7. A consequence is that the effectiveness of $\S 2$ as a judicially enforceable restriction in legislation depends on the hesitancy of legislatures to rely on the power of override in $\S 33(1)$.

8. I do not, of course, claim that differences in language impel these variations, and I cannot prove that the tendencies I discern are anything but observation of what the courts of the two countries have in fact done. 
categorization to play the central role in judicial decision, although courts may need some explicit balancing to avoid unacceptable results. In discerning the fundamental freedoms of section 2, Canadian courts might rely even more exclusively on conceptual approaches, because the explicit balancing standard of section 1 allows courts to balance when they believe they must. ${ }^{9}$

Since section 1 permits government justification of action that infringes section 2 freedoms, Canadian courts can find a violation of section 2's freedoms more easily than an American court would find a violation of the first amendment. But one would expect the flexibility that section 1 introduces to lead Canadian courts to invalidate fewer laws and practices as finally unconstitutional than their American counterparts. This is partly because the section 1 justification for regulation appears by its terms to grant more latitude to the political branches of government than does the language of the first amendment. It is also because most balancing tests tend to induce deference to legislative or executive wisdom. A court that is "balancing" considerations that were before the legislature may be more hesitant to conclude that the legislature made a mistake than a court inquiring whether the legislature ran afoul of some conceptual barrier.

Another reason we might expect Canadian courts to be less activist than American courts has to do not with constitutional language but with a long tradition of treating legislative judgments (at least ones that do not arguably violate principles governing division of powers) as finally authoritative. The Charter's novel principle of direct judicial invalidation based on individual rights ${ }^{10}$ could not be expected to alter drastically and swiftly engrained habits of deference to the political branches. Cases of the two Supreme Courts confirm these likely variations, although both Courts perceive similar values underlying free speech issues. ${ }^{11}$

Both American and Canadian courts have accepted broad rationales for freedom of speech and an accompanying expansive view of the speech that raises constitutional questions. In the United States, nonpolitical speech is protected as well as speech related to public affairs, while commercial communication for profit enjoys some lesser protection. Music and art count as speech. Forms of expression that indicate emotional intensity or capture attention are also protected even if less offensive words or methods could convey the same substance. ${ }^{12}$ The law of defamation is largely constitutionalized, and other private law doctrines impinging on expression

9. See A. Wayne Mackay, Freedom of Expression: Is It All Just Talk?, 68 Can Bar Rev 713, 730 (1989).

10. On the never entirely settled status of the 1960 Canadian Bill of Rights, see Peter W. Hogg, Constitutional Law of Canada 639-47 (Carswell Co, 2d ed 1985); Walter Surma Tarnopolsky, The Canadian Bill of Rights (McClelland \& Stewart, 2d ed 1975).

11. Commonality of evaluation is emphasized in Robert A. Sedler, The Constitutional Protection of Freedom of Religion, Expression, and Association in Canada and the United States: A Comparative Analysis, 20 Case W Res J Intl L 577 (1988).

12. Cohen $v$ Califormia, 403 US 15, 25-26 (1971). 
receive constitutional scrutiny. Controversially, the U.S. Supreme Court continues to leave obscene expression unprotected. Drawing the line between what is obscene and what is not remains a perplexing inquiry. ${ }^{13}$

In pre-Charter days, when freedom of speech was invoked mainly in connection with issues concerning the division of authority between the national and provincial governments, Canadian decisions suggested that only expression about political affairs was protected. But the advent of the Charter has led to coverage roughly similar to that of the American first amendment jurisprudence. One important exception concerns the common law of defamation and other common law bases of liability. According to present interpretation, common law rules enforcing private rights do not present Charter issues. ${ }^{14}$ An American's initial reaction is to wonder if all such judicial actions can continue to be beyond the scope of section 2 . If a provincial court held that ordinary political comment constituted defamation, would the Canadian Supreme Court conclude that no fundamental freedom had been violated?

In comprehending the present status of common law and Charter rights, one needs to recognize a crucial difference between common law in the United States and in Canada. In the United States, common law is generally state law; if common law doctrines do not infringe the federal Constitution or federal statutes, they are not a matter of federal concern and they are unreviewable by the Supreme Court. In Canada, Supreme Court powers are different. The Supreme Court is the court of last resort in a unitary system and may revise common law decisions of any lower court. ${ }^{15}$ Whether in some theoretical sense parts of the common law might be viewed as "federal law" or "provincial law," the Supreme Court can overturn what it regards as a bad common law judgment. Thus, in my example, the Supreme Court could develop the common law of defamation in light of Charter values. This structure reduces the practical significance of a rule that common law doctrines never directly infringe Charter rights. ${ }^{16}$

Attempting to summarize American doctrines for reviewing speech regulation is difficult because the law is complex and shifts subtly as new cases are decided. There are specific standards for determining when particular kinds of speech may be punished or made a ground of civil recovery. For

13. Obscene expression raises some issues closely related to those surrounding hate speech. I say very little about this important subject because it is being treated in another article for this symposium. See Kathleen Mahoney, The Canadian Constitutional Approach to Freedom of Expression in Hate Propaganda and Pornography, 55 L \& Contemp Probs 77 (Winter 1992).

14. See RWDSU v Dolphin Delivery, Lid., [1986] 2 SCR 573 (McIntyre); John A. Manwaring, Bringing the Common Law to the Bar of Justice: A Comment on the Decision in the Case of Dolphin Delivery, Ltd., 19 Ottawa L Rev 413 (1987).

15. Compare, for example, Murdock v City of Memphis, 87 US (20 Wall) 590 (1875) and Michigan v Long, 463 US 1032 (1983) with Constitution Act, 1867, §101 (UK) and Hogg, Constitutional Law of Canada at 141-42 (cited in note 10).

16. Nonetheless, the rule is anomalous in that (1) rules of private law under the Quebec Civil Code do raise Charter issues whereas similar common law rules do not, and (2) within a "common law" province, a judicial doctrine that has not raised a Charter issue becomes a Charter issue if enacted in identical form by a legislature. 
instance, public officials may recover for defamation only if the defendant wrote or spoke with knowledge of falsity or in reckless disregard of falsity. ${ }^{17}$

American law entertains a strong presumption against the validity of prior restraints. Only the very strongest reasons can justify government censorship of speech before it is made. This principle precluded government interference with the publication of highly classified material about the Vietnam conflict in the "Pentagon Papers." 18 In addition, it has made restricting pretrial publicity of criminal cases virtually impossible. ${ }^{19}$

In the last two decades, a principle prohibiting "content regulation" has emerged as a central doctrine of first amendment law. The fundamental idea is that some messages should not be favored over others. Certain differences in content are permissible bases of distinction; a message urging the commission of a crime may be treated differently from a message urging law obedience. But, in general, differences in viewpoint are not a permissible basis for distinction. Differences among categories in speech, for example, political as opposed to sexual speech, are also treated with suspicion. When the government interferes with speech in a manner that would normally be impermissible, its action will be sustained only if it is necessary to serve a compelling need and is narrowly drawn to achieve that end. ${ }^{20}$ In free speech cases using the "compelling interest" test, judges rarely sustain what the government has done.

Within the boundaries of speech that enjoys some protection, certain limited categories of speech are considered to have lower value, most notably commercial advertising and sexually explicit speech that falls short of obscenity. Regulation of these types of speech is subject to less stringent standards of review.

Less stringent standards also apply to government regulation that serves a purpose independent of the communication's substance. Thus, the government may restrict the size of billboards or limit the volume of sound trucks without satisfying a stringent compelling interest test.

Canadian constitutional doctrine, up to the present, is less complicated than that of the United States. There is both an expansive approach to what counts as freedom of speech and a developed balancing test under section 1 of the Charter. I will describe these features more fully when I consider recent Canadian Supreme Court decisions. For most troublesome cases, the section 1 balancing test raises the critical inquiry. In time, Canadian courts may develop various subsidiary doctrines similar in character if not in substance to those of the United States; but the contextualized standard under section 1 will probably limit such doctrinal proliferation by making much of it unnecessary. The following treatment of specific substantive areas illustrates the general remarks I have made thus far.

17. New York Times v Sullivan, 376 US 254 (1964).

18. New York Times v United States, 403 US 713 (1971).

19. See Nebraska Press Ass 'n $v$ Sluart, 427 US 539 (1976).

20. Perry Education Ass 'n v Perry Local Educators' Ass 'n, 460 US 37 (1983). 


\section{Subversive Advocacy, Criminal Solicitation, and Other Crime-Related Speech}

A central aspect of the American development of freedom of speech has involved subversive advocacy, one form of extreme dissent. The famous language of "clear and present danger" was first used in Justice Oliver Wendell Holmes's 1919 opinion for the Supreme Court in Schenck v. United States, which upheld a conviction under the Espionage Act. ${ }^{21}$ He said, "The question in every case is whether the words are used in such circumstances and are of such a nature as to create a clear and present danger that they will bring about the substantive evils that Congress has a right to prevent." 22 For most of the justices who then accepted this language, and perhaps for Holmes himself, the formula was not very protective of speech. In a case decided by the Court within a week of Schenck, a man was punished for helping to publish twelve articles of small circulation that were favorable to Germany and that called those who resisted the draft "technically ... wrong" but more "sinned against than sinning." 23 Thousands of people were convicted and sent to jail during World War I for comment no stronger than this.

In subsequent cases, Justices Holmes and Louis Brandeis, in dissent, developed "clear and present danger" into a doctrine that significantly protected speech. They said that if speech promoting subversion was to be punished, the danger had to be great and its occurrence proximately close. These opinions failed to make clear whether the test required actual present danger or only an aim to produce a harm quickly. Additionally, the question of whether the test applied at all to speech that explicitly urged the commission of a particular crime remained unanswered.

During the 1930s and 1940s, "clear and present danger" emerged as the critical test for subversive advocacy and as the standard for a wide range of free speech problems. ${ }^{24}$ Its "reformulation" by a plurality in Dennis $v$. United States, ${ }^{25}$ a post-war prosecution of American Communist Party leaders, represented a severe setback for free speech. The Court asked if "the gravity of the 'evil,' discounted by its improbability, justifies such invasion of free speech as is necessary to avoid the danger." Under this standard, speech could be punished if it posed some threat of a very great danger in a rather distant future. As other justices pointed out, American courts were hardly in a position to estimate how likely it was that domestic Communist speech would contribute to a violent revolution many years thence. Justice Felix Frankfurter, concurring in the result, urged a "candid and informed weighing

21. 249 US 47 (1919).

22. Id at 52 .

23. Frohwerk v United States, 249 US 204, 208 (1919).

24. One of the problems was contempt of court, with the Supreme Court sharply restricting that common law offense. See Bridges $v$ Califormia, 314 US 252 (1941). When the Ontario Court of Appeals considered contempt of court by scandalizing the court in 1987, it reached a similar conclusion. See $R$. $v$ Kopylo, 62 OR (2d) 449 (1987).

25. 341 US $494,510(1951)$. 
of the competing interests" in free speech and national security. But whatever potential this ad hoc balancing might have had to promote serious judicial scrutiny was surrendered later in the opinion when Frankfurter said that Congress's judgment in adjusting the interests should be set aside "only if there is no reasonable basis for it." 26

In the 1960s, the Court announced what remains the standard for subversive speech. Overturning the conviction under a criminal syndicalism statute of a speaker at a Ku Klux Klan rally, the Court per curiam said that a state may not "forbid or proscribe advocacy of the use of force or of law violation except where such advocacy is directed to inciting or producing imminent lawless action and is likely to produce such action."27 According to this test, called the Brandenburg test, imminent lawless action must be the speaker's objective and be actually likely to happen. In a 1973 decision overturning a demonstrator's conviction for disorderly conduct, the Court indicated that "imminent" meant likely to occur within a very short span of time. ${ }^{28}$ The defendant had remarked to his friends, "We'll take the fucking street later"; 29 presumably he meant later in that day. According to the Court, even if his words could be taken to urge illegal action at a later time, his conviction had to be overturned in the absence of evidence that he intended to produce "imminent disorder." 30 No doubt, the word "imminent" contains some degree of flexibility, but the Court has adopted a very stringent standard for punishment of speech likely to encourage criminal action.

The extent of the Brandenburg test's applicability remains unclear. The Court's cases have thus far involved only public political advocacy. Does the test also set a general constitutional limit on punishment for urging criminal acts? If a sister writes her brother urging that he steal money from their parents, is that protected speech if the theft is not to happen for a few weeks or the brother is unlikely to do what the sister asks? American cases have generally assumed that ordinary criminal solicitation does not present a serious first amendment problem, and I have argued that Brandenburg should not cover such situations; but no case contains a developed or satisfactory explanation of the distinction between public advocacy and private solicitation. ${ }^{31}$

What is the relationship between free speech and the many communications that commonly occur as aspects of criminal activities? Words can be exchanged to form agreements to commit crimes; words are used among participants to plan and carry out crimes; words commit harms by threat or deception. Many crimes in the standard catalogue almost invariably involve verbal utterances, and others often do. I have suggested that an

\footnotetext{
26. Id at 525.

27. Brandenburg v Ohio, 395 US 444 (1969).

28. Hess v Indiana, 414 US 105 (1973).

29. Id at 107 .

30. Id at 109 .

31. In the context of offers of legal services, the Court has drawn a similar distinction. See Ohralik v Ohio State Bar Ass in, 436 US 447 (1978), and In re Primus, 436 US 412 (1978).
} 
utterance lies outside free expression if it directly alters the social environment by "doing" something rather than telling something or recommending something. ${ }^{32}$ Examples are words of agreement that commit people to action and threats that introduce a new danger into victims' lives. It is fair to say that American courts have not yet felt a need to explain why typical utterances connected to crime lie outside first amendment protection. $^{33}$

Direct issues about subversive or revolutionary speech have not been considered by the Canadian Supreme Court since the advent of the Charter. In Boucher v. The King, ${ }^{34}$ a 1951 case that interpreted a broadly worded prohibition on seditious libel, the Court held that a Jehovah's Witness's attack on various groups was not within the statute's scope. The case is often cited as an application of free speech principles operating prior to the Charter. That decision supports narrow construction of provisions regulating dangerous speech, but sheds little light on the bounds of section 2 .

Language in recent Canadian Supreme Court cases suggests very broad protection of "criminal language," indeed coverage so broad that one wonders if the justices had considered the full implications of their words. The most important opinions were in a trio of prostitution cases. ${ }^{35}$ The defendants challenged as a violation of freedom of expression the Criminal Code prohibition against communicating in a public place for the purpose of engaging in prostitution or obtaining a prostitute's services. All six justices deciding the cases agreed that public solicitation for prostitution was covered by freedom of expression under section 2 . However, four sustained the Code provision as a permissible limitation under section 1 .

On the coverage of section 2(b), Justice Wilson's dissent is most important, because three members of the majority indicate agreement with her reasoning. ${ }^{36}$ She states that the government's purpose is to restrict the content of expression by singling out meanings that are not to be conveyed, rather than dealing directly with a variety of harmful consequences. ${ }^{37}$ "Whether the citizen is negotiating for the purchase of a Van Gogh or a sexual encounter, section 2(b) of the Charter protects that person's freedom to communicate with his or her vendor." 38

Since prostitution per se is not illegal in Canada, it remains uncertain how Justice Wilson would treat solicitation to commit an independently criminal act, each instance of which might be regarded as involving a harmful consequence. On this point, Justice Lamer is much clearer. He says that

32. See generally Greenawalt, Speech, Crime, and the Uses of Language at 57-71 (cited in note *).

33. State $v$ Robertson, 293 Or 402, 649 P2d 569 (1982), does have an extensive discussion of threats that neither seek nor threaten actions that are independently criminal, a common situation for blackmail or extortion and for the broader crime of criminal coercion.

34. [1951] SCR 265.

35. Reference re $\$ \S 193,195.1(1)(c)$ of the Criminal Code (Man.), [1990] I SCR 1123; R. v Stagnitta, [1990] I SCR 1226; R. v Skimer, [1990] I SCR 1235.

36. Reference re Criminal Code (Man.), [1990] I SCR 1123, 1134 (Dickson).

37. Id at 1205 (Wilson).

38. Id at 1206 . 
section 2(b) "protects all content of expression irrespective of the meaning or message sought to be conveyed." 39 He identifies provisions in the criminal code whose actus reus may consist wholly or partially of speech, for instance, counselling a party and uttering threats. Justice Lamer then suggests that criminal prohibition of messages conveyed through traditional forms of expression like speaking or writing should be viewed as a restriction on freedom of expression. ${ }^{40}$ Direct acts of violence and direct attacks on the physical integrity and liberty of another are unprotected. In Regina $v$. Keegstra, to which I shall return, Chief Justice Dickson, writing for the majority, indicates that threats of violence fall within the scope of section 2 (b) because they are classified according to the content of their meaning. Only direct acts of violence are unprotected. ${ }^{41}$

One cannot reach confident conclusions about how the Canadian Supreme Court will resolve the many difficult free speech questions it has yet to face. But if one tries to piece together comments in opinions subscribed to by majorities, the following seems to be the present law in Canada. Speaking and writing are covered by section 2(b), even when intimately related to independent criminal activities. No distinctions are drawn between informing, urging, offering, and threatening, distinctions I believe are crucial. ${ }^{42}$ If an offer of services is protected, as the prostitution cases indicate, so should be the acceptance of an offer. Thus, agreement between two people to commit a crime would also be covered by section 2 (b).

What would be the practical consequences of this expansive view of free speech? Of course, section 1 would allow most criminal punishment to stand. But as we shall see, application of section 1 involves a serious test of the significance of the government's objective and of the need to suppress expression. Even if a criminal prohibition is otherwise constitutionally permissible, the governmental objective may not be weighty enough to survive section 1 review, or punishment of agreements and offers to commit the crime may not really be needed. If the courts engage in the genuine review section 1 is said to require, they must end up saying that in respect to some acts that are properly crimes, the government cannot punish agreements, offers, counseling, or perhaps even participation that involves only utterances. ${ }^{43}$ I am dubious the courts will do this. For standard sorts of crimes, even minor ones whose enactment may have been unwise, I think

39. Id at 1181 (Lamer).

40. Id at 1184 .

41. R. v Keegstra, [1990] 3 SCR 697, 731-33 (Dickson). Justice McLachlin, joined by two other justices in dissent, suggests that threats of violence do not count as expression under section 2(b). Id at $830-31$.

42. These are developed in Greenawalt, Speech, Crime, and the Uses of Language at 13-15, chs 3-6 (cited in note *).

43. I am referring here to someone who agrees to commit a crime and whose participation is limited to instructing others what physical acts to perform. It appears that all he does is covered by $\S 2$ (b). Of course, it may be said that the acts of other participants are attributed to him by standard criminal law doctrine, but the application of that doctrine must also be subject to scrutiny under $\S \S 2(\mathrm{~b})$ and $\mathrm{I}$. 
courts will find the speech values in these communicative activities too weak to warrant more than perfunctory review under section 1 . Should that course be followed, an unfortunate effect of the Supreme Court's present direction may be a softening of the stringency of section 1 review when more serious speech is involved. ${ }^{44}$ If American courts have yet to explain the constitutional status of most criminal speech, perhaps the Canadian Supreme Court has reached too quickly for an overly expansive generalization that fails to recognize significant differences in the nature of utterances.

\section{IV}

\section{Fighting Words and Hate Speech: Responsive Violence and INDEPENDENT HARMS}

Among the most controversial modern questions about freedom of speech is the proper treatment of strong insults and "hate speech." Many strong insults use coarse language in a highly derogatory way ("You are a fucking bastard."), but others avoid any single shocking word. Many strong insults are cast in terms of race, religion, ethnic origin, gender, or sexual preference. Some language that is contemptuous or hateful toward members of such groups occurs in contexts other than individual insults.

The leading American case on direct insults remains Chaplinsky $v$. New Hampshire, ${ }^{45}$ decided half a century ago. A Jehovah's Witness who had been warned about his proselytizing by a city marshal responded by calling the marshal "a God damned racketeer" and "a damned Fascist."46 The defendant was convicted under a law that prohibited calling someone an offensive or derisive name. The state supreme court had construed the statute to cover only words that "men of common intelligence would understand [to be] likely to cause an average addressee to fight." The Supreme Court, affirming the conviction, said:

There are certain well-defined and narrowly limited classes of speech, the prevention and punishment of which have never been thought to raise any Constitutional problem. These include the lewd and obscene, the profane, the libelous, and the insulting or "fighting" words-those which by their very utterance inflict injury or tend to incite an immediate breach of the peace .... [S] uch utterances are no essential part of any exposition of ideas, and are of such slight social value as a step to truth that any benefit that may be derived from them is clearly outweighed by the social interest in order and morality. ${ }^{47}$

Two developments since Chaplinsky have substantially undercut its rationale and its permissive attitude toward punishment of fighting words; but

44. For a possible alternative to this result, see Justice McLachlin's opinion for the majority in $R$. $v$ Commiltee for the Commonwealth of Canada, [1991] 1 SCR 139, 232-33, in which she wrote: "The state should not be obliged to defend in the courts its restriction of expression which does not raise the values and interests traditionally associated with the free speech guarantee. Indeed, a failure to invest section 2(b) with meaningful content reflective of those principles threatens to trivialize the Charter guarantee of free expression."

45. 315 US 568 (1942).

46. Id at 571-72.

47. Id. 
no alternative approach has yet taken its place, and its central language has not been explicitly disavowed. The opinion says "such utterances are no essential part of any exposition of ideas . . . " Fighting words cannot, unfortunately, be dismissed as lacking any expressive value. In meaning, they attribute negative characteristics to their object. Group epithets, such as "kike" or "wop" or "nigger," call to mind negative qualities that some people associate with a group, such as laziness, greed, dishonesty, stupidity, and vulgarity, and make a strongly negative evaluation of the group.

Is the expressive value of such utterances negligible because the same ideas could be stated in less troubling language? In one of the first developments since Chaplinsky, the Court rejected this approach in a 1971 case, overturning a conviction for wearing a jacket that said "Fuck the Draft." Justice Harlan's opinion for the Court in Cohen $v$. Califormia indicated that people are free to choose the words that best reflect their feelings, and strong words may better convey to listeners the intensity of feeling than more conventional language. ${ }^{48}$

The second important development since Chaplinsky has been the Court's invalidation of statutes directed at offensive language, on grounds of overbreadth and vagueness. Provisions have been found too vague to guide conduct and overbroad in reaching too much speech that is protected. Under Supreme Court doctrine, when a statute suffers the defect of substantial overbreadth, it improperly chills free speech, and it may not be used even against those whose own speech otherwise might properly be punished.

The basic idea that likely responsive violence can be the basis for punishing insulting words remains from Chaplinsky and lies close to the subject covered by the Brandenburg principle. It would be odd to say that public insults can be punished on a lower probability of violence than actual urgings of illegal violent acts. Under Brandenburg, imminent lawless action must be likely; something similar should be needed if fighting words are punished for their propensity to cause immediate violence. Chaplinsky's suggestion that an "average addressee" must be likely to fight, however, is inappropriate or misleading, and almost certainly reflects the implicit sense that actors are male. When one takes women, children, and older people of both sexes into account, it is doubtful whether any words are likely to cause the "average addressee" to fight. The focus on groups of addressees other than young males raises a more deeply troubling question as to whether likely violence in the particular instance should be the standard for punishment. In otherwise similar circumstances, a white male of twenty-five calls an Afro-American male of twenty-five a "nigger," and six white males of twenty-five call an AfroAmerican female of sixty a "nigger." Can it really be that the first male is constitutionally punishable and the other six males are not? That would be a

48. 403 US 15, 25-26 (1971). The Court also distinguished Chaplinsky on the ground that the defendant in Cohen had spoken to the world at large, rather than a specific individual or group, and thus his speech was less likely to provoke a violent response. 
disturbing conclusion, and the problem suggests that other bases for punishing strong insults may be important.

Abusive words can wound their targets deeply, offending them and a much broader audience as well. Perhaps they may have a negative effect on public communication by endangering the civility of discourse. Group epithets can reinforce feelings of prejudice, inferiority, and hostility among groups, thus contributing to social patterns of domination. Which, if any, of these bases underlie punishment of insulting words in the United States?

Perhaps the Supreme Court has not completely rejected the idea that offensiveness of expression could underlie conviction, but in Cohen $v$. California and other cases striking down criminal provisions for overbreadth and vagueness, it has strongly suggested that in our society people must be hardy enough to tolerate very strong expression if they do not avoid it. The Court has permitted a ban on some words on daytime radio, ${ }^{49}$ regulation of the location of theaters specializing in adult movies, ${ }^{50}$ and discipline of a high school student who used "vulgar and offensive" language at a school assembly, ${ }^{51}$ but it has not sustained any absolute prohibition of forms of speech because they are thought to be offensive.

Nor has the Supreme Court held that protecting the civility of discourse is a sufficient basis for general restrictions on the manner in which ideas are expressed. The government may forbid uncivil remarks in formal settings like the courtroom, but expression in open public settings may not be curtailed on that basis. ${ }^{52}$

Matters are less clear concerning emotional wounding and reinforcement of hostility, prejudice, and domination. When angry speakers hurl insults, they presumably think or feel that their words are true. Their primary object is not to wound, although they may be aware that effect will happen and may even welcome it. On other occasions, however, language is chosen more deliberately. Particular words understood as a challenge to fight may be chosen for just that purpose. Or the speaker, not overtly inviting a fight, may have a dominant objective to provoke enough anger to cause a fight. Speakers sometimes consciously choose language to make their targets feel degraded and hated, independent of whether the words reflect their own feelings. In each of these settings, the words have minimal expressive value. Words that invite a fight are closely similar to those that propose joint commission of an illegal act; they alter the normative setting. Words that are consciously used to provoke a fight or to wound and humiliate constitute

49. FCC v Pacifica Foundation, 438 US 726, 748-51 (1978).

50. Young $v$ American Mini Theatres, 427 US 50 (1976); City of Renton v Playtime Theatres, 475 US 41 (1986).

51. Bethel School District v Fraser, 478 US 675, 683 (1986).

52. A borderline setting may be a public meeting that is for adults but that has a particular function that is not duplicated elsewhere. I have in mind a public meeting of a local school board or other small unit of the government. People who want to participate must, in a sense, attend, and they form a kind of captive audience, but the entire public is welcome to attend and speak. The Supreme Court has indicated that offensiveness cannot be a basis for restriction in such settings. See, for example, Rosenfeld v New Jersey, 408 US 901, $901-02,909$ (1972). 
manipulative uses of language rather than (mainly) expressions of honest feeling. Wounding words are psychic attacks similar to certain physical assaults, such as slaps or pinches, that cause no serious physical pain.

Since no American decision really sorts out these matters in any detail, defining the constitutional law in this area is hard. Chaplinsky refers to words "which by their very utterance inflict injury or tend to incite an immediate breach of the peace." 53 It is arguable that words that primarily wound are punishable. But line-drawing problems are severe. Separating an intent to humiliate from a crudely expressed outpouring of feelings is difficult, and motives are often mixed. Federal and state statutes do forbid making telephone calls in order to harass someone else, and courts generally have sustained these laws. ${ }^{54}$ Perhaps more generally, penalties are acceptable when abusive language that causes extreme distress accompanies an aim to intimidate someone from exercising legally protected rights or when one person initiates contact with another just to harass her, as when people taunt strangers with racial epithets. A general criminal prohibition of abusive words designed to hurt and humiliate probably would be judged unconstitutional.

Civil penalties are a somewhat different story. Standards for civil damages can be more vague than standards acceptable for criminal liability. The tort of infliction of emotional distress requires extremely outrageous conduct and severe emotional distress. The Supreme Court has held that recovery on that theory is not permissible for parodies of important public figures, ${ }^{55}$ but in private circumstances, outrageously abusive language that causes extreme distress is probably compensable.

When focusing on long-term harms, one encounters problems that are among the most difficult for any democratic legal order. In the first instance, the relevant domain of utterances expands significantly. The harm from group epithets can occur not only when words are directed toward members of the group but also when members are not present. For example, men who use denigrating expressions about women in conversations with each other may impair gender equality just as much as men who address denigrating expressions toward women. Moreover, the harm can occur whether or not the speaker chooses particularly crude or offensive language. Even neutralsounding scientific language can be deeply worrisome, as we see when people deny that many Jews were killed during World War II or claim that AfroAmericans possess less intelligence on the average than whites.

The damage of long-term effects of speech, and the accompanying motive to suppress, flow much more directly from the content of the idea expressed than is true for any of the other justifications for regulation. Assuming that the state may suppress speech likely to cause immediate violence, to wound, to offend, or to disturb civility, the underlying notion is that the speaker could state whatever facts and values he believes in, including his assessment of

53. Chaplinsky, 315 US at 572 (emphasis added).

54. See, for example, United States $v$ Lampley, 573 F2d 783 (3d Cir 1978).

55. Hustler Magazine v Faluell, 485 US 46 (1988). 
particular individuals (when the assessment is not false and defamatory), if only he cleans up his manner of expression. But if concern is with the longterm effect of language that denigrates members of groups, even polite language can cause much of the same harm. To admit that such language can be punished is to strike much more severely at traditional concepts of free speech, and certainly flies in the face of a principle of "no content regulation." Yet allowing such speech may perpetuate or cause unjust inequalities. For liberal democracies committed to equality and to liberty of speech, the dilemma is painful.

The leading U.S. Supreme Court case on the subject, now nearly forty years old, vividly portrays the problem. ${ }^{56}$ An Illinois law forbade publications portraying "depravity, criminality, unchastity, or lack of virtue of a class of citizens, of any race, color, creed or religion [in a way that exposes those citizens] to contempt, derision, or obloquy or which is productive of breach of the peace or riots." 57 Beauharnais had organized distribution of a leaflet asking city officials to resist the invasion of the Negro and warning that if "the need to prevent the white race from becoming mongrelized by the negro will not unite us, then the aggressions, . . . rapes, robberies, knives, guns and marijuana of the negro, surely will."58 The Court upheld the conviction, assimilating the publication to group libel, instances in which a small group is defamed in such a way that the damaging remark falls on all group members. The Court mentioned the danger of racial riots, which a legislature might reasonably think is increased by racist speech.

The leaflet's collection of claimed facts and opinions certainly did not contribute to a healthy racial climate. Yet, under ordinary free speech standards, the opinions, for example, about the undesirability of whites having children with blacks, would be protected. The asserted facts are either too vague to be shown to be false or are subject to an interpretation that would allow them to be defended as true. For example, Beauharnais could argue that talk about the aggressions of the Negro obviously did not mean that all blacks committed aggression but only that a higher percentage of blacks than whites did so.

Developments since Beauharnais have led most commentators to suppose that the decision, itself by a 5-4 margin, is no longer authoritative. Cohen and other cases give speakers increased latitude to choose the way they express themselves, and "content discrimination" has become very difficult to justify. The Illinois law, forbidding publications that portray a lack of virtue of a class of citizens of any race in a way that exposes them to contempt or derision, was certainly content discrimination in the strong sense of viewpoint discrimination. When American Nazis claimed a right to march in Skokie, a city with many Jewish survivors of the Holocaust, the Seventh Circuit Court of

56. See Beauharmais v Illinois, 343 US 250 (1952).

57. Id at 251 .

58. Id at 252 . 
Appeals assumed that Beauharnais no longer controlled and that a Nazi march could not altogether be foreclosed. 59

Nevertheless, a U.S. Supreme Court somewhat less protective of speech might draw from Beauharmais and some more recent currents in American society to permit punishment of speech that denigrates groups. Sensitivity about such speech has grown on many college campuses, public as well as private, and some universities have adopted restrictive guidelines. Many people believe that educational institutions, even those of the state, can set higher levels of civility and respect than the society at large. In addition, employment law has seen an expanded view of impermissible harassment by race and gender. Harassment includes denigrating speech, and it is now seen as appropriate for people to be disciplined or lose jobs if they engage in such harassment. These developments, along with international concern about hate speech, may over time produce a consensus approving content discrimination when directed against speech that sharply supports group prejudice and unjust domination.

The Supreme Court of Canada addressed the law on hate speech in three decisions issued on December 13, 1990.60 In each case, a seven member court (two justices not sitting) passed on the validity of a statute that a defendant had violated. Chief Justice Dickson wrote the three majority opinions; Justice McLachlin, joined by two other justices, wrote dissents.

In Regina v. Keegstra, an Alberta high school teacher had described Jews as "treacherous," "subversive," "sadistic," "money-loving," "power-hungry," and "child killers," who were responsible for wars and revolutions and who "created the Holocaust to gain sympathy." 61 He was convicted under section $319(2)$ of the Canadian Criminal Code, which prohibits communicating statements, other than in private conversation, that willfully promote hatred against any identifiable group, distinguished by color, race, religion, or ethnic origin. ${ }^{2}$ Among other defenses, a person cannot be convicted if he establishes the truth of the statements.

Canada (Human Rights Commission) v. Taylor 63 involved a civil provision, section 13(1) of the Canadian Human Rights Act, which prohibits telephonically communicating information likely to expose a person or group to hatred or contempt on the basis of, inter alia, race or religion. Taylor, who made recorded messages denigrating the Jewish race and religion, challenged the statute and a cease and desist order issued against him. Since the analysis

59. See Collin v Smith, 578 F2d 1197 (7th Cir 1978).

60. See R. v Keegstra, [1990] 3 SCR 697; R. v Andrews, [1990] 3 SCR 870; Canada (Human Rights Comm 'n) y Taylor, [1990] 3 SCR 892.

61. [1990] 3 SCR 697, 714.

62. In $R$. $v$ Andrews, [1990] $3 \mathrm{SCR}$ at 874-75, leaders of a white nationalist organization were punished under the same provisions for publishing a newspaper directed against "coloureds," who are allegedly responsible for increases in violent crime, who do not believe in democracy, and who "harbour a hatred for white people," and against Zionists who "fabricated the "Holocaust Hoax."

63. [1990] 3 SCR 892. 
in the three cases is closely similar, I shall concentrate on Keegstra, making a few comments about Taylor.

The Court's first inquiry under the Charter was whether the guarantee of freedom of expression extends to the public and willful promotion of hatred against an identifiable group. Drawing from Irwin Toy, ${ }^{64}$ an earlier decision on commercial speech, Chief Justice Dickson in his majority opinion wrote, "Apart from rare cases where expression is communicated in a physically violent form, the Court thus viewed the fundamental nature of the freedom of expression as ensuring that if the activity conveys or attempts to convey a meaning, it has expressive content and prima facie falls within the scope of the guarantee.' '65 Keegstra's teachings clearly qualified for protection.

Also relevant to the coverage of section 2(b) was the government's purpose to restrict freedom of expression. Since section 319(2) of the Criminal Code singled out particular meanings not to be conveyed, those promoting hate against groups, its aim was to restrict expressive content.

The majority opinion then turned to section 1, which permits such reasonable limits on constitutional freedoms "prescribed by law as can be demonstrably justified in a free and democratic society." Regina $v$. Oakes ${ }^{66}$ had established the standard approach for section 1 analysis. Under this twopronged approach, the state's objective must be of "pressing and substantial concern in a free and democratic society" and the impugned measure must meet a test of proportionality. ${ }^{67}$

The Court concluded that hate propaganda represents a pressing and substantial concern in a free and democratic society. It supported this conclusion by noting Charter provisions supporting equality and multiculturalism, and various international obligations to combat discrimination, including advocacy of racial or religious hatred.

Relying in part on the influential findings of the 1965 Cohen Committee, ${ }^{68}$ Chief Justice Dickson observed that hate speech can cause emotional damage to members of the target group, with grave psychological and social consequences, and can create serious discord among cultural groups, subtly altering views even when listeners consciously reject its ideas. ${ }^{69}$

The proportionality inquiry had three parts: Was the law rationally connected to the objective? Did the law impair freedom of expression "as little as possible?" Were the effects of the law proportional to the objective? The Chief Justice stated that it was proper for this inquiry to consider the relationship between the restricted expression and the principles at the core of section 2(b). ${ }^{70} \mathrm{He}$ concluded that "expression intended to promote the

64. Irwin Toy Ltd. v Quebec (Attorney General), [1989] I SCR 927.

65. Keegstra, [1990] 3 SCR at 729 (quoting Irwin Toy, [1989] 1 SCR at 969).

66. [1986] I SCR 103.

67. Id at 138.39 (Dickson).

68. Report to the Minister of Justice of the Special Committee on Hate Propaganda in Canada (Queen's Printer, 1966).

69. Keegstra, [1990] 3 SCR at 745-49 (Dickson).

70. Id at 760 . 
hatred of identifiable groups is of limited importance when measured against free expression values," 71 since it contributes little to truth and tends to frustrate the autonomy and political expression of members of the targeted groups. The opinion made clear that it did not endorse inflexible "levels of scrutiny," undoubtedly a reference to American constitutional approaches; rather, a court is to determine "the manner in which section 2(b) values are engaged in the circumstances of an appeal." 72

Chief Justice Dickson did not doubt that in its aim the criminal provision was rationally related to reducing hate speech. That, in itself, would satisfy American rationality review, but not the rationality component under section 1 of the Charter. He agreed with the dissenters that if the law in fact has no effect or works in opposition to admirable objectives, it fails the test of rationality. In answer to the argument that prosecution gives hate-mongers media attention, Chief Justice Dickson responded that prosecutions may reassure members of targeted groups and show society's reprobation of hate speech. ${ }^{73}$

The "minimal impairment" criterion raised issues of vagueness and overbreadth and the possibility that speech other than hate propaganda would be chilled. Chief Justice Dickson noted the statutory exception for private speech and that conviction requires an accused subjectively to desire or foresee as nearly certain the promotion of hatred, the most intense form of dislike. Doubting that a statute must provide a truth defense for those who intentionally promote hatred, the Chief Justice deemed acceptable the failure to excuse negligent or innocent error. In answer to a claim that section 319 (2) was excessive because non-criminal responses could more effectively combat the harm caused by hate propaganda, the opinion declared that government need not rely upon the kind of intervention that is least intrusive and approved a combination of diverse measures.

Finally, the majority of the Court weighed the importance of the state's objective against the effects of the limit on a Charter freedom. Stressing again the "enormous importance" of the objective underlying the Code provision, Chief Justice Dickson reiterated that the restricted category of expression was "only tenuously connected with the values underlying the guarantee of freedom of speech," and easily concluded that the negative effects did not outweigh the advantages of the law. ${ }^{74}$

Justice McLachlin's dissenting opinion, joined by two other justices, agreed with the majority that Keegstra's speech was protected by section 2(b) and that the federal law was aimed at expression. She suggested that Keegstra's words did not fall into an unprotected category of violent threats and that any extension of unprotected speech under section 2(b) would be

\footnotetext{
71. Id at 762 .

72. Id at 767 .

73. Id at 769 .

74. Id at 787 .
} 
inappropriate. ${ }^{75}$ Like the majority, the dissenters turned to section 1 to resolve the most difficult issues in the case, and they employed the same formulations in their review. Justice McLachlin quickly concluded that the state's objective was pressing and substantial. Her disagreement with the majority concerned the proportionality of the regulation with the harm prevented.

The dissent emphasized that free expression is fundamental to Canadian democracy and that limitations on expression tend to "chill" speech beyond their target. 76 Section 319(2) fails the "rationality" test because the statute may well discourage defensible expression while dignifying hate speech by its suppression. Noting that pre-Hitler Germany had vigorously prosecuted laws like Canada's anti-hate law, the opinion denied that there is "a strong and evident connection between the criminalization of hate propaganda and its suppression."77

On "minimum impairment," the dissent emphasized vagueness and overbreadth, finding the word "hatred" to be more amorphous in content than the majority. The dissenters also worried that judges and juries would be likely to infer an intent to promote hatred from unpopular speech. Justice McLachlin argued that a speaker might have legitimate objectives and also intend to promote active dislike of a group, or foresee that that might happen. ${ }^{78}$ For the dissenters, the track record of prosecutions for material that should have remained protected was sufficient to show the statute's overbreadth. ${ }^{79}$ In light of other available responses, including civil human rights legislation, "the very fact of criminalization itself may be argued to represent an excessive response to the problem of hate propagation." 80

The dissenters also disagreed with the majority about the comparison between the right to expression and the benefit of the legislation. The restriction of individual viewpoints that bear on many subjects of discussion is a serious infringement of expression, and the gains from the law are tenuous. Any questionable benefit is outweighed by the infringement.

In Taylor, the majority sustained the provision of the Canadian Human Rights Act that forbids using the telephone to expose a person or a group to hatred or contempt, as it applies to race and religion. Because the provision is civil rather than criminal, the majority of the Court accepted the absence of a requirement that the defendant intend to discriminate and the lack of any defense for truth. The majority's easy approval of a cease and desist order,

75. Id at 829-30 (McLachlin).

76. Id at 850 .

77. Id at 854 .

78. Id at $856-57$.

79. Id at 859. The majority noted that some of these actions were under other provisions, but that does not eliminate altogether the evidence they provide that authorities may reach beyond what is covered by a narrow reading of $\$ 319(2)$.

80. Id at 860 . 
which underlay a contempt judgment, indicated a much more comfortable attitude toward prior restraints than one would find in American courts. ${ }^{81}$

The same three justices dissented. Emphasizing the broad range of communications that might be covered, Justice McLachlin found the provision wanting on all three prongs of the proportionality requirement. ${ }^{82}$

One peculiar aspect of broad application was not noted by either opinion. Religions usually consist of views as well as traditions and practices. If anything warrants hatred or contempt, some actual or potential religious views do, because religious views may support the most contemptible attitudes and practices. Suppose, for example, that right wing members of the South African Dutch Reformed Church moved to Canada and preached that colored peoples of various sorts are inferior to whites and that apartheid should be established in Canada. A citizen telephones neighbors and warns them against this hateful religion then being established in their town. Saying the doctrines are hateful is likely to expose members and the group to hatred or contempt, so it seems the citizen would have violated the provision, which recognizes no defense for honest religious disagreement (or any disagreement, religious or otherwise). Unless Canadian courts are willing to swallow the principle that vigorous religious disagreement is always inappropriate over the telephone, this kind of case seems one in which the impairment of legitimate expression is very great.

Some important features of these cases deserve special mention. The opinions are directed at statutory language and do not focus attention on the facts of the particular cases. In the actual cases, litigants had no strong claim to protection that other violators would lack. But other cases could be different. I have mentioned the citizen with a conscientious and wellgrounded abhorrence to a group's religious beliefs. A problem of more general concern is "hate speech" directed at the dominant white majority. This problem is hardly fanciful; in Great Britain a substantial percentage of "hate speech" prosecutions have been against members of minorities. Much of what the Court says about the pressing concern to suppress hate speech does not apply to hate speech of small minorities against dominant groups. Presumably, whether such speech can constitutionally be punished remains an open question.

In contrast to the vast bulk of free speech cases in the United States, the majority and the dissenters agree on the formulation of standards applicable to the problems. The careful and fairly elaborate criteria for section 1 turn out to be less stringent than the rigorous compelling interest test, under which legislation rarely survives, and more stringent than most other American balancing formulas, under which legislation rarely fails. One may expect a paradoxical effect on the stability of doctrine and on results. Because the section 1 approach of Regina $v$. Oakes, and especially its proportionality

81. Taylor, [1990] 3 SCR at 931-40 (Dickson).

82. Id at 958-70 (McLachlin). 
components, permit so much to be taken into account, it seems unlikely that justices will find a need to discard the formula, although nuances of difference in the significance of the approach have emerged. ${ }^{83}$ However, since future justices will probably feel relatively free to emphasize factors they regard as appropriate, not believing precedent constrains them greatly on the status and weight to be given particular factors, the Court's declaration of the status of some provisions will not be a very sure guide about what a changed Court some years later will decide about other provisions. Particular categories such as prior restraint and content discrimination carry much less importance in Canada than in the United States. The nuanced, contextualized approach encouraged by section 1 can yield relative flexibility of result under relatively stable, open-ended criteria of evaluation.

\section{$\mathrm{V}$ \\ Symbolic Speech}

Very roughly, symbolic speech is expression that takes the form of action that is not a common means of expression. Since all language is symbolic, saying just where ordinary speech ends and symbolic speech begins is somewhat artificial. And it is not clear that symbolic speech should be a constitutionally significant category. What may be more important is whether the state's reason for impinging on activity relates to its expressive quality. I shall return briefly to that question later, but for now I will focus on what is commonly considered symbolic speech.

A student wears a black armband in school to protest a war, a registrant burns his draft card, a protester burns an American flag, a homeless person stands nude in front of City Hall to make a statement about the inadequacy of public efforts to deal with homelessness. These are all forms of symbolic speech. The dominant aim of the actor is to communicate a message, and his action is understood in that way by observers. Although it might be said that every action "expresses something" about the actor and is understood by others to do so, not every action raises a free speech problem. There must be a concrete attempt to communicate a message.

In dealing with symbolic speech, the U.S. Supreme Court has drawn a sharp distinction. One standard of review is used when a regulation is not directed at communication; another standard is used when regulation is purposely aimed at communication. The idea of a regulation "directed at communication" is very close to the idea of content discrimination. A regulation that is aimed at communication typically is directed against an undesired content.

Regulation is not addressed to communication when it forbids acts for reasons having nothing to do with the fact that some subcategory of the acts is communicative. Public nudity is forbidden for reasons unrelated to some

83. These are most notable in the opinions in the recent case of $R$. Committee for the Commonwealth of Canada, [1991] 1 SCR 139. 
people's appearing nude in public to communicate messages. One possible approach to such cases is that the first amendment has no bearing on them; if people happen to violate laws, their communicative motivation would give them no standing to be treated differently from others who violate the laws. Another possible approach is to say that the communicative aim does give the acts a special position because of the first amendment. In its major case on the subject, the U.S. Supreme Court equivocated.

In United States $v$. O'Brien, ${ }^{84} \mathrm{O}^{\prime}$ Brien was prosecuted for destroying a draft card. Exercising extraordinary deference to congressional intent, the Court said that Congress had reasons for people to keep draft cards that did not relate to expression. Everyone who knew anything about the statute adopted by Congress understood that Congress was upset about the symbolism of draft card burning and wanted to stop the burning of cards in protest, but the Court declined to investigate motiv́ation. It therefore swallowed as plausible bases for the statute the reasons suggested by the government why registrants needed to have their cards. So, despite the contrary reality, the Court treated the case as one in which the purpose of legislation had nothing to do with expression. Chief Justice Warren's opinion then said,

We cannot accept the view that an apparently limitless variety of conduct can be lateled "speech" whenever the person engaging in the conduct intends thereby to express an idea. However, even on the assumption that the alleged communicative element in O'Brien's conduct is sufficient to bring into play the First Amendment, it does not necessarily follow that the destruction of a registration certificate is constitutionally protected activity. ${ }^{85}$

The opinion then proceeded to announce what has come to be called the O'Brien test:

[A] government regulation otherwise is sufficiently justified if it is within the constitutional power of the government; if it furthers an important or substantial governmental interest; if the governmental interest is unrelated to the suppression of free expression; and if the incidental restriction on alleged First Amendment freedoms is no greater than is essential to the furtherance of that interest. ${ }^{86}$

In demanding that the government's interest be substantial and that the restriction on expression be no greater than is essential to further the interest, the $O^{\prime} B r i e n$ test sounds fairly stringent; but the Court comfortably sustained the conviction. The Supreme Court and other courts using the O'Brien standard in the various areas to which it has now been applied almost invariably end up approving the government's restrictive action. The O'Brien approach, minus its equivocation, does represent a position that some significant review is appropriate when expressive action runs afoul of regulation not aimed at expression, but the review has proved pretty relaxed.

A 1990 religious freedom case raises some question whether the present Court will continue to indulge even the form of $O^{\prime} B r i e n$. The apparently settled principle under the free exercise clause of the first amendment, which

84. 391 US 367 (1968).

85. Id at 376 .

86. Id at 377 . 
prohibits regulation of religious activities and beliefs, was that when a person violated an "ordinary" law because of religious conscience, a court would sustain the regulation only if the government had a compelling interest that could not be satisfied if an exemption were given. In one well-known case, the California Supreme Court had held that a prohibition on the use of peyote could not be applied against members of the Native American Church who used peyote during worship services. ${ }^{87}$ But in Employment Division $v$. Smith, ${ }^{88}$ the Supreme Court announced not only that this result was wrong, but that the entire compelling interest approach to this subject was misguided. If a law is otherwise constitutional, the state needs to meet no further burden to apply the law against persons acting from religious conscience. This result surprised and appalled most scholars of the religion clauses, not to mention persons in religious groups who pay attention to the Court's work. What I want to note here is the possible relevance of the case for the O'Brien test.

Prior to Smith, a person violating a "neutral" law from religious conscience seemed to benefit from a more stringent form of review than a person violating a neutral law in order to express an idea. That is, the compelling interest free exercise test seemed to be more favorable to an actor than the $O$ 'Brien free speech test. This result seemed sensible. A person who acts from religious conscience feels he has no alternative; a person expressing an idea wants to do so effectively, but probably does not ordinarily feel some inner compulsion to use a particular means. Especially given the country's long history of regarding religious conscience as a source of overriding obligation, the different approaches to the two grounds for violating a regulation seemed appropriate.

After Smith, the person acting from religious conscience is treated like an ordinary violator whose conduct is wholly unprotected. Can it be that the person deciding to express himself or herself is going to be treated better? I am skeptical. No doubt, arguments relating to the function of speech can be made that the O'Brien test, as applied to these situations, should not suffer the fate of the free exercise compelling interest test. Moreover, courts are not always coherent in their approaches to related problems, and the O'Brien test may already be so weak that its formal abandonment is unnecessary. Still, Smith casts a big shadow over the continued vitality of this employment of the O'Brien standard.

When regulation is directed at expression, review is much more stringent than under O'Brien. In Tinker v. Des Moines Independent Community School District, ${ }^{89}$ school authorities forbade students from wearing black armbands to protest the Vietnam War. The school's interest was precisely in discouraging this form of constant communication about the controversial topic of the war; it had no other reason not to want students wearing black armbands. Had a

87. People v Woody, 61 Cal 2d 716, 394 P2d 813 (1964).

88. 494 US 872 (1990). See also Peyote Way Church of God v Thornburgh, 922 F2d 1210 (5th Cir $1991)$

89. 393 US 503 (1969). 
similar regulation by a city of its citizens been involved, the law would clearly have been unconstitutional. Given the state's concern for the school setting and disciplined education, the Supreme Court said that the student had a right to express herself if she did so without " "materially and substantially interfer[ing] with the requirements of appropriate discipline in the operation of the school'... or imping[ing] upon the rights of other students." 90

The two recent cases on flag burning are examples of the difficulty a government faces if its law is viewed as directed at communication. In 1989 the Court easily concluded in Texas $v$. Johnson ${ }^{91}$ that the asserted reasons for prohibiting flag desecration, to avoid violence and preserve the flag as a symbol of nationhood and national unity, failed "the most exacting scrutiny"92 as constitutional justifications for prohibiting acts of flag burning. The following year, the federal Flag Protection Act suffered a similar fate in United States v. Eichman. ${ }^{93}$

What is doctrinally interesting about the flag burning cases is not the application of stringent review once it is determined that a statute is directed at communication, but the intricacies of deciding what counts as being directed at communication. It is oversimplifying only a little to say that Justice Brennan's opinions for the Court, in his last two terms, treat both statutes as aimed at communications hostile to national unity and the existing government. No doubt, this is mainly what legislators had in mind. On this view, the regulation involves blatant discrimination against particular viewpoints, and the flag burning cases are therefore rather easy (unless one treats flag destruction as so sensitive that it calls for treatment disparate from general first amendment principles).

A close look at the actual statutory language in the two cases presents somewhat more complex problems. The Texas statute forbade damaging or mistreating the flag "in a way that the actor knows will seriously offend."94 The Court mentions but does not develop the point that a person, say using a flag to start a campfire, for instance, might violate the statute without having any message to communicate. The Court seems to assume that a statute narrowly designed to prevent flag desecration leading to immediate violence would not be directed at communication. The idea apparently is that the state is concerned with preventing violence, not the content of messages. The Court does not acknowledge that the structural relation between flag desecration and causing offense is similar to the relation between flag desecration and causing violence. The state can say it only wants to prevent hurt feelings, not to suppress any particular kind of message. Of course, both for offense and violence, some kinds of messages are more dangerous than others, so the content of a message will affect application of the statute.

90. Id at 509 (quoting Burnside v Byars, 363 F2d 744, 749 (5th Cir 1966))

91. 491 US 397 (1989).

92. Id at 412 .

93. $110 \mathrm{~S} \mathrm{Ci} 2404$ (1990).

94. Tex Penal Code Ann $\$ 42.09(b)$ (Vernon 1991). 
Perhaps that is enough to make a statute directed at communication; or perhaps it is reasonable to suppose that when a law is cast in terms of "seriously offend," the legislature is really striking at messages it finds seriously offensive, an impermissible constitutional purpose.

Congress tried to repair the weakness in the Texas statute by broadly forbidding physical mutilation or burning of the flag. This more clearly reached some behavior that was not intended to communicate. Justice Stevens in dissent emphasizes that the statute plainly forbids flag burning on behalf of a wide variety of messages, not only flag burning hostile to the government or national unity. Some of the Court's language suggests that a statute is aimed at communication if it aims to suppress all messages conveyed by flag burning, even apart from the strong correlation of flag burning and messages hostile to the government or country. Such a statute would be aimed at communication, and it would disfavor flag burning as a mode of communication, but it would not involve content discrimination in the sense of viewpoint discrimination. The argument for "exacting scrutiny" of statutes disfavoring a mode of communication is less obvious than the argument for such scrutiny of viewpoint discrimination.

There is another element of significance. The main asserted justification for the federal law was preserving the flag as a national symbol. That is an aim to protect the flag's force as a communicative symbol. That symbol stands for things such as national unity and republican government, and the statute gives it a protection not afforded other symbols. This objective makes the statute aimed at communication in a sense that does not depend on the messages flag burners are trying to convey, and indeed does not depend on whether they are trying to convey any message at all.

My remarks here are far from exhaustive. I have shown, however, that a statute could be aimed at communication in many different senses. The need for most exacting scrutiny is less obvious for some of those senses than others. Johnson and Eichman reveal those complexities, but the differences tend not to be clarified, but rather elided in pursuit of rhetorical objectives.

The language in Keegstra suggests the Canadian approach to symbolic speech. If the government is aiming at the content of messages, as the U.S. Supreme Court decided was occurring in the two flag destruction statutes, then the protection of section 2(b) would apply, and the standards under section 1 would determine whether restriction were permissible. According to Chief Justice Dickson, if the individual is engaging in expression, very broadly defined, and the government's purpose is not to restrict expression (as the U.S. Supreme Court said was true in $O^{\prime}$ Brien), then section 2(b) does not apply unless the accused can show that his "activity supports rather than undermines the principles and values upon which freedom of expression is based."95 Thus someone who appeared nude to communicate a message would have to convince a court that this promoted rather than interfered with

95. Keegstra, [1990] 3 SCR at 730 (Dickson). 
open discussion and consideration. If he won on that issue, he would then face the section 1 standards. Justice McLachlin's view is rather similar, that when the government aims to accomplish a goal unrelated to expression, a complainant who argues for initial coverage under section 2(b) must show that his or her expression implicates one of the values of free expression.

\section{VI}

\section{Public Demonstrations}

I shall say relatively little about a complex area of first amendment law: regulation of public demonstrations. The key features are: In its streets and parks, the state must permit some demonstrations. ${ }^{96}$ It cannot close off these traditionally public forums from those who choose to express themselves by demonstrating. It may, however, engage in reasonable restrictions of the time, place, and manner of demonstrations. ${ }^{97}$ There is considerable latitude about where and when demonstrations may be allowed, but restrictions are subject to significant judicial review. The courts' inquiry now includes whether alternative channels of communication are left open, and whether a regulation is narrowly tailored to serve the government's interest; but the government need not show that the regulation of the time, place, or manner of public speech is the least intrusive possible. ${ }^{98}$ If restrictions reflect viewpoint discrimination, favoring some perspectives over others, they will be held invalid unless the government can satisfy the compelling interest test. ${ }^{99}$ And if the restrictions confer unfettered discretion on executive officials, they will also be held invalid, in large part because wide discretion would allow officials to engage in viewpoint discrimination. If demonstrations threaten some danger of a violent response by others, the government has an essential responsibility to protect the demonstrators and stop the violent bystanders, ${ }^{100}$ but in extreme circumstances it can demand that demonstrators themselves stop. ${ }^{101}$

These basic principles apply not only to places that are traditional sites of public expression, but also to areas the government decides to open up to such expression. ${ }^{102}$ In other areas that are not traditional forums and have not been opened up, the government may preclude demonstrations altogether or allow them on a much more limited basis, but the rules against viewpoint discrimination and excessive discretion apply. In striking down a law that generally forbade demonstrations near public schools, but permitted demonstrations related to school labor disputes, the Supreme Court held that content discrimination favoring discussion of some subjects over others is also

96. Hague v Committee for Indus. Organization, 307 US 496 (1939).

97. Cox v New Hampshire, 312 US 569, 576 (1941).

98. See Ward v Rock Against Racism, 491 US 781, 796-802 (1989).

99. See Boos v Barry, 485 US 312 (1988).

100. Compare Edwards v South Carolina, 372 US 229 (1963) and Gregory v Cily of Chicago, 394 US

111, 113-26 (1969) (Black concurring).

101. Feiner $v$ New York, 340 US 315 (1951).

102. Perry Education Ass 'n, 460 US at 45-46. 
unconstitutional ${ }^{103}$ unless the content distinction bears a reasonable relation to use of that space. ${ }^{104}$

Very roughly, we can see operating here principles close to those that control symbolic speech. If the government's concern is not to suppress particular messages, but to control impediments to traffic or similar nuisances, it has considerable leeway so long as it does not close off traditional forums. But any action taken that restricts a demonstration because the message is controversial or unpopular is presumptively unconstitutional. When the state aims at the communication, it is unlikely to succeed. It is just this unifying principle that makes it doubtful whether symbolic speech is itself a significant category. The state's reasons for restriction often play a much more prominent role than whether an activity, looked at by itself, counts as straightforward speech (such as posting election signs on utility poles ${ }^{105}$ ), as "speech plus action" in demonstrations, or as symbolic speech.

In some recent decisions, the Supreme Court has suggested that time, place, and manner review is essentially the same as the $O^{\prime} B$ rien test. ${ }^{106}$ From the perspective of state purposes, this coalescence makes sense, but there are disparate factors to be considered. Street demonstrations are a unique and important form of communication; they cannot be closed off completely, and regulation that sharply limits them should be carefully reviewed. This would suggest that time, place, and manner review in that context should be more stringent than $O^{\prime}$ Brien. But on the other hand, some forms of symbolic speech represent the way in which a person truly wants to express himself, and may be part of the substance of the communication. ${ }^{107}$ This consideration suggests that such symbolic speech should receive more protection than some matters covered by time, place, and manner.

In Canada, some pre-Charter cases suggested that demonstrations are collective action rather than a form of speech and that public authorities may have the same power to regulate public property as private individuals have to control use of their property. ${ }^{108}$ But it is now clearly established that demonstrations are expression within section $2(b)$ and that regulation of

103. Police Dep't v Mosley, 408 US 92 (1972); see Carey v Brown, 447 US 455 (1980). Perhaps these cases may be regarded as involving "place" restrictions on traditional forums, broadly understood to include public streets, that would be permissible except for the distinctions they draw.

104. See United States v Kokinda, $110 \mathrm{~S}$ Ct 3115 (1990).

105. See Members of the City Council $v$ Taxpayers for Vincent, 466 US 789 (1984); Metromedia, Inc. $v$ City of San Diego, 453 US 490 (1981).

106. Rock Against Racism, 491 US at 798; Clark $v$ Community for Creative Non-Violence, 468 US 288, 298-99 (1984).

107. In Community for Creative Non-Violence, 468 US 288, it was argued that the act of homeless people sleeping overnight in tents near the White House was itself expressive, not merely "facilitative" in making it possible for homeless people to participate easily. Susan Williams has suggested that types of content discrimination are involved, even when the government has no purpose to discriminate on bases of content, if regulation forecloses expressive aspects of speech (in which event, she claims, no alternative is adequate) or systematically disadvantages certain content categories of speech. Susan H. Williams, Content Discrimination and the First Amendment, 139 U Pa L Rev $615(1991)$.

108. See generally Roman Stoykewych, Street Legal: Constitutional Protection of Public Demonstration in Canada, 43 U Toronto Fac L Rev 43, 57-58 (1985). 
public property is constrained. ${ }^{109}$ In a recent case involving distribution of pamphlets and discussion by a political organization at an airport, Regina $v$. Committee for the Commonwealth of Canada, ${ }^{110}$ all justices agreed that some public spaces must be open for public expression and that government regulations of spaces owned by it are subject to review. The opinions indicated agreement with the U.S. Supreme Court that streets and parks are open to public expression, but they rejected any rigid "public forum" approach as insensitively focusing on only one relevant factor. ${ }^{111}$ The justices differed on the right approach to determining whether expression in a public place is covered by section 2(b), and to some degree also on the specific elements of analysis under section 1. All the justices agreed, however, that a bar on distributing political pamphlets and undertaking political advocacy in airports violated section 2(b) and was not saved under section 1. A majority found that the government policy was not "prescribed by law" as section 1 requires, ${ }^{112}$ and also that it failed other section 1 standards I have discussed in connection with Keegstra. Insofar as the case is a guide to how ordinary demonstrations will be treated, Committee for the Commonwealth suggests fairly robust protection.

\section{VII}

\section{CoNCLUSION}

Free speech law in the United States and Canada is characterized by strong similarities and significant differences. In the free speech cases it has decided under the Charter, the Canadian Supreme Court has mainly put questions in terms of statutory provisions' facial constitutionality. It has not focused on individual situations in the way the U.S. Supreme Court commonly does when deciding whether laws are unconstitutional in their applications to particular facts. Perhaps partly because they are beginning with a clean slate, the Canadian justices have written opinions that explicate large domains. Although this often happens in American free speech jurisprudence, other cases are narrow in focus. The Canadian Supreme Court is developing a distinctive balancing approach under section 1 and avoids relying as much upon categorical analysis as do U.S. courts. That approach leads it to sustain some measures that would probably be held unconstitutional in the United States.

109. RWDSU v Dolphin Delivery Ltd., [1986] 2 SCR 573 (§ 2(b) said not to apply because regulation of secondary picketing was according to common law principles).

110. [1991] I SCR 139.

111. See, for example, the opinion of Justice L'Heureux-Dubé, id at 201-02, citing, inter alia, Daniel A. Farber \& John E. Nowak, The Misleading Nature of Public Forum Analysis: Content and Context in First Amendment Adjudication, 70 Va L Rev 1219 (1984); Richard J. Moon, Access to Public and Private Property under Freedom of Expression, 20 Ottawa L Rev 339 (1988).

112. Some justices believed the relevant regulation did not forbid the political activities involved and that the government policy to stop them was not "prescribed by law"; others thought the regulation did cover the activities but suffered so much vagueness it did not create a limit prescribed by law. $R . v$ Committee for the Commonwealth of Canada, [1991] I SCR 139. 
Both Supreme Courts have an expansive sense of free speech that is based on the centrality of speech for liberal democracy. Typically, Canadian opinions have discussed American cases and commentary, but they decline to import American doctrines as they stand. American decisions have yet to pay much attention to what is happening in Canada, but that time may come. 
